\title{
燃え止まり型木質耐火構造部材の工学的設計法に関する研究

\author{
小型試験に基づく燃えしろ・燃え止まり層の設計法の検討
}

\section{ENGINEERING APPROACH TO THE DESIGN OF WOODEN FIREPROOF STRUCTURAL ELEMENTS BASED ON THE SACRIFICE-LAYER CONCEPT}

Optimum design of the wood-based protection layers using bench-scale tests

\author{
山口智世 ${ }^{* 1}$, 上川大輔 ${ }^{* 2}$, 長谷見 雄二 ${ }^{* 3}$, 安井 昇 ${ }^{* 4}$,
}

高 瀬＼cjkstart椋*5, 宮林 正 幸*6, 鈴木 淳 一*7

\section{Tomoyo YAMAGUCHI, Daisuke KAMIKAWA, Yuji HASEMI, Noboru YASUI, Ryo TAKASE, Masayuki MIYABAYASHI and Jun-ichi SUZUKI}

\begin{abstract}
Strategy for the development of wooden fireproof structural elements based on the sacrifice-layer concept through bench-scale tests is studied through a series of bench scale tests on the design composed of sacrifice layer (chemically untreated wood), barrier (fire retardant treated wood) and loadbearing part (untreated wood). It has revealed importance of the design of the sacrifice layer to reach the glowing combustion temperature at around the end of the heating for the achievement of self-extinguishment. It has resulted in the development of Japanese-cedar based 1-hour fireproof beam only with small test apparatuses available almost everywhere, demonstrating its advantage for the technical development in the districts not accessible to large furnaces.
\end{abstract}

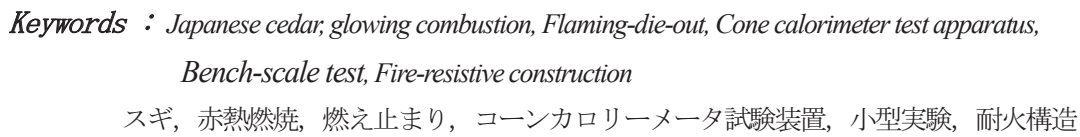

1. はじめに

\section{1. 背景と目的}

近年、人工林の管理や環境配慮型社会の実現などの観点から木材 利用促進の必要性が叫ばれている。また 2000 年以降、建築基準法 の改正や公共建築物木材利用促進法を背景に、大規模・多用途な建 築への活用を見据えた様々な木質耐火構造部材の開発が進められて いる。今後、住宅等の既存市場の他、大規模建築や特殊建築物を木 材利用の主要な市場として開拓するには、準耐火・耐火構造の開発 が不可欠である。

特に木質耐火構造は、 $\mathrm{RC}$ 造や鉄骨造とは異なり、構造部材自体 が可燃物であるため、荷重支持部に引火させずに「自消する」こと が必要である。木材の自消の有無は赤熱燃焼の継続に左右されるこ とが知られている 12) が、火災加熱終了後に赤熱然燒が停止する条件 等には不明な点が多い。そのため部材開発は、大型試験体の実験で 試行錯誤的に行われ、効率的な開発を困難にしている。木質耐火構 造は主に、荷重負担する木材を不燃被覆する方法(被覆型)、荷重を
鋼材に負担させ、大断面の木材で覆って補剛・断熱する方法(ハイブ リッド型)、荷重負担する木材を燃えしろとなる木材が覆い、その間 に燃焼の進行を遮断する燃え止まり層を設ける方法(燃え止まり型) の 3 タイプに分かれる。

本研究では、その中では実用化が最も遅れているものの、部材レ ベルでの総木質化が可能な燃え止まり型耐火部材を対象とする。特 に、燃えしろ・燃え止まり層における赤熱燃焼の制御可能性を小型 試験により把握して、目標とする耐火性能を有する部材を設計する 方法を検討する。想定する仕様は、部材全体を一般的な製材工場で 加工できる仕様の開発を目標としている。ここでは、無処理の木材 (以下、無処理材)を構造部材、その 外側に難燃処理した木材(以下、難燃 処理材)を燃え止まり層として接着、 更にその外側に無処理材を燃えしろ 層として接着した 3 層の構成とした (図 1)。

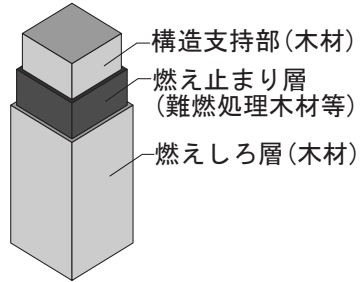

図 1 燃え止まり型木質耐火構造部材
本稿の実験については，文献 3），4），5），6）で口頭発表した。

$* 1$ (株竹中工務店 工修(当時 早稲田大学大学院)

*2 (国研) 森林総合研究所 博士(工学)

*3 早稲田大学理工学術院 教授. 工博

*4 早稲田大学理工学研究所 招聘研究員 · 博士 (工学)

*5 早稲田大学大学院 修士課程

*6 (有)ティー・イー・コンサルティング

*7 国土交通省国土技術政策総合研究所 主任研究官·博士 (工学)
Takenaka Corporation, M.Eng.(formerly Waseda University)

Forestry \& Forest Products Research Institute, Dr.Eng.

Prof., Dept. of Architecture, Waseda University, Dr.Eng.

Visiting Researcher, RISE, Waseda University, Dr.Eng.

Graduate School of Waseda University

T.E.Consulting Inc.

National Institute for Land Infrastructure Management, Dr.Eng. 


\section{2. 研究の流れ}

これまでの燃え止まり型木質耐火構造部材の設計では、火災加熱 から燃え止まり層・構造支持部への影響を抑制するため、燃えしろ 層を厚くする傾向があった。しかし、燃えしろ層が厚いと加熱終了 後も赤熱燃焼が継続して自消し難くさせる可能性があることを示す 既往研究 12) もある。そのため、燃え止まり型耐火構造では、加熱中 と加熱終了後の燃えしろ層、燃え止まり層、各々に異なる機能が必 要になる。燃えしろ層は、加熱中は燃え止まり層を保護してその難 燃性の低下を抑制するとともに、加熱終了後の赤熱燃焼を、吸熱作 用により然え止まり層で停止できるよう厚さを設計する必要がある。 一方、燃え止まり層は、加熱中の難燃薬剤の分解による燃えしろ層 の温度上昇の抑制と分解時の燃え止まり層自体の自消性(難燃性)の 確保が必要である。この場合、燃えしろ層は加熱中の被覆効果の面 では厚い方が有利となるが、赤熱然焼の抑制には薄い方が有利なた め、その厚さには適正範囲があると予想される。そこで、1 時間耐 火構造を想定した仕様設計の検討を次の 3 段階に分けて行った。

(1) 定常加熱されるスギ無処理材による赤熱燃焼と自消機構の把握

燃えしろ層における火災加熱時・加熱終了後の自消・赤熱燃焼 の一般的様態を把握するために、加熱強度の制御と、定常加熱が 可能なコーンカロリーメータ試験装置を熱源とする定常加熱実 験を行った。同装置で加熱中の重量減少を測定できる限界厚さの 無処理材の内部の温度分布を測定し、赤熱燃焼が加熱終了後も持 続する部位・加熱条件を把握した。

(2) 火災加熱される燃え止まり型小試験体を用いた自消機構の把握

加熱終了後の無処理材の自消が困難になるのは、材深部で赤熱 燃焼に至る場合であると(1)により確認できた。そこで然えしろ層 の赤熱燃焼を制御し、木材の分解を燃え止まり層内で停止させる のに必要な難燃性能を、燃えしろ層厚さとの関係で把握するため に、小型加熱実験を行った。燃えしろ層・燃え止まり層及び構造 支持部の一部を断面方向に再現する小型試験体を製作し、 1 時間 の標準耐火加熱のもとで、各種仕様における加熱終了後の自消の 有無を把握した。

(3) 燃え止まり型木質耐火構造の梁の設計と有効性の検証

(2)により燃え止まり層内での自消が期待できる見通しが得ら れた燃えしろ層・燃え止まり層の組み合わせに基づいて燃え止ま り型木質耐火構造の梁を設計し、実大断面をもつ試験体により非 載荷で 1 時間の耐火構造の加熱実験を行った。

本研究では、対象樹種を、国内での需要拡大が最も望まれている ものの燃焼制御が困難で耐火木造の開発が遅れているスギとし、難 燃薬剤は最も汎用性の高い窒素リン酸系とした。

\section{2. 定常加熱されるスギ無処理材による赤熱燃焼と自消機構の把握}

燃えしろ層の加熱時の被覆効果と加熱終了後の赤熱燃焼の持続に ついて一般的な傾向を把握するために、無処理材に対して一定の入 射熱流束条件下での加熱実験を行った。

試験体にはスギ小試験体を、加熱にはコーンカロリーメータ試験 装置に付属するコーンヒーターを用いた。まず、加熱条件(入射熱流 束)を実験パラメータとして、内部温度の推移から、燃えしろ層の熱 分解及び赤熱燃焼、更に燃え止まり層を設けた場合の薬剤分解の各 反応過程がどの段階で始まるのかを把握した(以下、内部温度測定実
験)。次に、異なる加熱条件(加熱強度・時間)に曝された試験体を、 脱炉後に、常温無風下で自然放冷する実験を実施した。特に自然放 冷中における試験体の内部温度と重量変化から、加熱条件と自消性 状の関係を定量的に把握した(以下、自消機構把握実験)。

\section{1 実験概要}

Cone Calorie MeterIII(東洋精機製)を用い、発熱速度の他、内部 温度及び重量を測定した。

\subsection{1 試験体}

既存のコーンカロリーメータ試験装置では、定常加熱時に重量減 少を測定できる試験体厚さの限界が $40 \mathrm{~mm}$ である。したがって試験 体は、無処理スギラミナ $20 \mathrm{~mm}$ 厚 2 枚をレゾルシノール樹脂系接着 剂で接着した $100 \mathrm{~mm} \times 100 \mathrm{~mm} \times$ 厚さ $40 \mathrm{~mm}$ のスギ集成材とした。

\section{1 .2 測定項目及び実験方法}

本実験では、内部温度測定実験及び自消機構把握実験の 2 種類の 実験を行った。以下に各実験の測定項目及び実験方法を示す。

(1) 内部温度測定実験

加熱強度を $25,35,50 \mathrm{~kW} / \mathrm{m}^{2}$ 、加熱時間を 80 分とし、図 2 に 示すように配置した熱電対で、加熱中の表面温度及び内部温度を 測定した。表面・内部温度の測定には、 $\mathrm{K}$ 型シース熱電対 $(\varphi 1.0 \mathrm{~mm})$ を用い、裏面から垂直に挿入し、試験中に移動しない ように注意深く裏面に固定した。裏面温度の測定には、ディスク 型熱電対を用いた。

(2) 自消機構把握実験

加熱時間を $10,30,60$ 分、加熱強度は $25,35,50 \mathrm{~kW} / \mathrm{m}^{2}$ を基本 とした。加熱終了後は試験体をホルダーから外し、非加熱面を断 熱材（セラミックファイバーブランケット厚さ約 $30 \mathrm{~mm}$ 、密度 約 $\left.110 \mathrm{~kg} / \mathrm{m}^{3}\right)$ で断熱した上で、室温 $28^{\circ} \mathrm{C}$ 無風下にて自然放冷し、 自消の有無を判断した。自消の判断は、表面温度が赤熱燃焼の限 界温度である $450^{\circ} \mathrm{C}$ に比べ十分低下し、かつ重量減少が停止した 時点と定めた。ある条件を境に自消の有無が変化した場合は、両 条件の中間の条件で実験し、自消条件のより詳細な把握を試みた。 試験体の内部温度分布及び重量を主に測定するが、これらは同時 測定できないため、同一条件で実施する試験体を 2 種類用意した。 また両試験体で、表面温度(1 分または 5 分)を熱映像(FLIR 社製、 測定範囲 $670^{\circ} \mathrm{C}$ )にて測定した。内部温度分布測定用の試験体では、 内部温度及び表面温度 $\left[{ }^{\circ} \mathrm{C}\right]$ を、重量測定用試験体では、重量変化 $[\mathrm{g}]$ 及び表面温度 $\left[{ }^{\circ} \mathrm{C}\right]$ を測定した。なお、自然放冷中の重量は、電子天 秤(メトラートレド社製)で測定した。

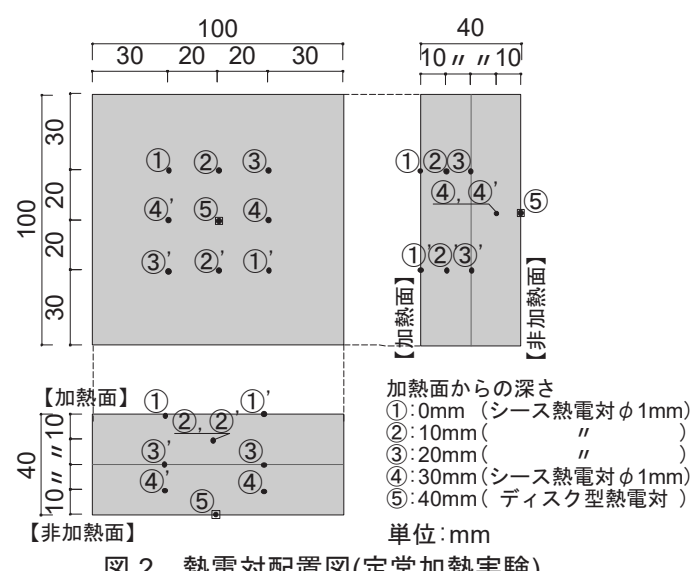

図 2 熱電対配置図(定常加熱実験) 


\section{2 実験結果・考察}

\subsection{1. 各加熱条件における加熱中の木材内部温度の推移}

各加熱条件における内部温度の推移を図 3 に、赤熱燃焼、炭化、 難燃薬剤の分解がそれぞれ $450^{\circ} \mathrm{C} 、 260^{\circ} \mathrm{C} 、 195^{\circ} \mathrm{C}$ に起こる $\left.33,4,7\right)$ と し、その到達深さと時刻を図 4 に示寸。木材の炭化が $260^{\circ} \mathrm{C}$ で始ま ると仮定して、図 4 から深さごとに $260^{\circ} \mathrm{C}$ に達した時間から加熱中 の炭化速度を推定すると、加熱強度 $25 \mathrm{~kW} / \mathrm{m}^{2}$ で約 $0.67 \mathrm{~mm} /$ 分、同 $35 \mathrm{~kW} / \mathrm{m}^{2}$ で約 $0.8 \sim 1.0 \mathrm{~mm} /$ 分、同 $50 \mathrm{~kW} / \mathrm{m}^{2}$ で約 $1.0 \mathrm{~mm} /$ 分と、肉 厚木材の標準耐火加熱時と同等かやや大きい。大気中での定常加熱 時之耐火炉における標準加熱時で試験体の加熱条件がどれほど近い かには不明な点が多いが、一般的に酸素濃度が低い耐火炉よりも、 コーンカロリーメータでの加熱の方が、はやく燃え進むと考えられ る。本論文では、炭化速度が大きくは変わらないため、本実験の結 果から、1 時間の標準加熱と放冷に対し自消を達成する燃え止まり 型木質耐火構造部材仕様の設計に向けた考察を行う。

\subsection{2 各加熱条件における自消機構の把握}

重量比は、実験中の試験体の重量を加熱前の重量で除した值とし、 重量比減少速度が 0 になった時点で自消したと判断した。表 1 に各 加熱条件における自消機構把握実験結果の一覧を示すが、加熱終了 後 20 分程度で自消した場合と、概称然え尽きるまで重量減少が継 続した場合の 2 グループに分けることができた。

自消した場合と燃焼継続した場合の加熱条件における、加熱終了 後を含む試験体内部及び表面の温度等測定例を図 5、図 6 に示寸。

内部温度は、深さ $10 \mathrm{~mm}$ と $20 \mathrm{~mm}$ の間で加熱時には大きな差が あるが、加熱終了後は、自消の有無を問わず、時間とともにこの 2 点の温度の高低が逆転する傾向がみられる。これより、深さ $10 \mathrm{~mm}$ の温度は表面の熱流入出の影響を強く受けるのに対し、深さ $20 \mathrm{~mm}$ 以遠では表面の熱収支の影響を短時間には受け難いことがわかる。 自消した場合(図 5)、内部温度は表面温度の降下に伴って降下寸るの に対し、燃焼継続した場合(図 6)は、試験体内部の深さ $20 \sim 40 \mathrm{~mm}$ で 380 $480^{\circ} \mathrm{C}$ を保っていることから、少なくとも局部的には赤熱 燃焼していると考えられる。これは、木材が赤熱燃焼を始めた場合、 表面から $10 \mathrm{~mm}$ 程度までの浅部では、加熱終了後に䨌囲気温度が低 下寸れば熱損失により温度降下し、赤熱燃焼が停止するのに対し、 $20 \mathrm{~mm}$ 程度以遠では試験体表面からの熱損失の影響は小さく、赤熱 燃焼が続き易いことを示している。

また表面温度も、燃焼継続した場合(図 6)では、温度上昇が加熱終 了時の $1 / 2$ に降下寸るまでに加熱時間(30 分)以上かかるなど、緩慢 である。このように、材深部で赤熱燃焼が続く場合に表面温度の低 下が遅れるのは、材深部で赤熱燃焼が続くと、表面に近い部分も材 深部からの熱移動により加熱されるからだと考えられる。

脱炉までの総発熱量（発熱速度の時間積分）は、定常加熱実験に おいて、熱分解領域の深さを代表する指標と考えられるが、本実験 では約 $118 \mathrm{MJ} / \mathrm{m}^{2}$ 以上のとき燃焼継続していることがわかる。無処 理材が自消するのは、本実験の加熱強度の範囲では 20 分以内に限 られることから、無処理スギ材の燃えしろ層だけでは一般的な耐火 構造の実現は困難と考えられるが、局所火源が想定される場合に無 処理材で自消寸る条件を示した既往実験の結果 8 ) は、本実験におけ る無処理材の自消限界の範囲内となっている。
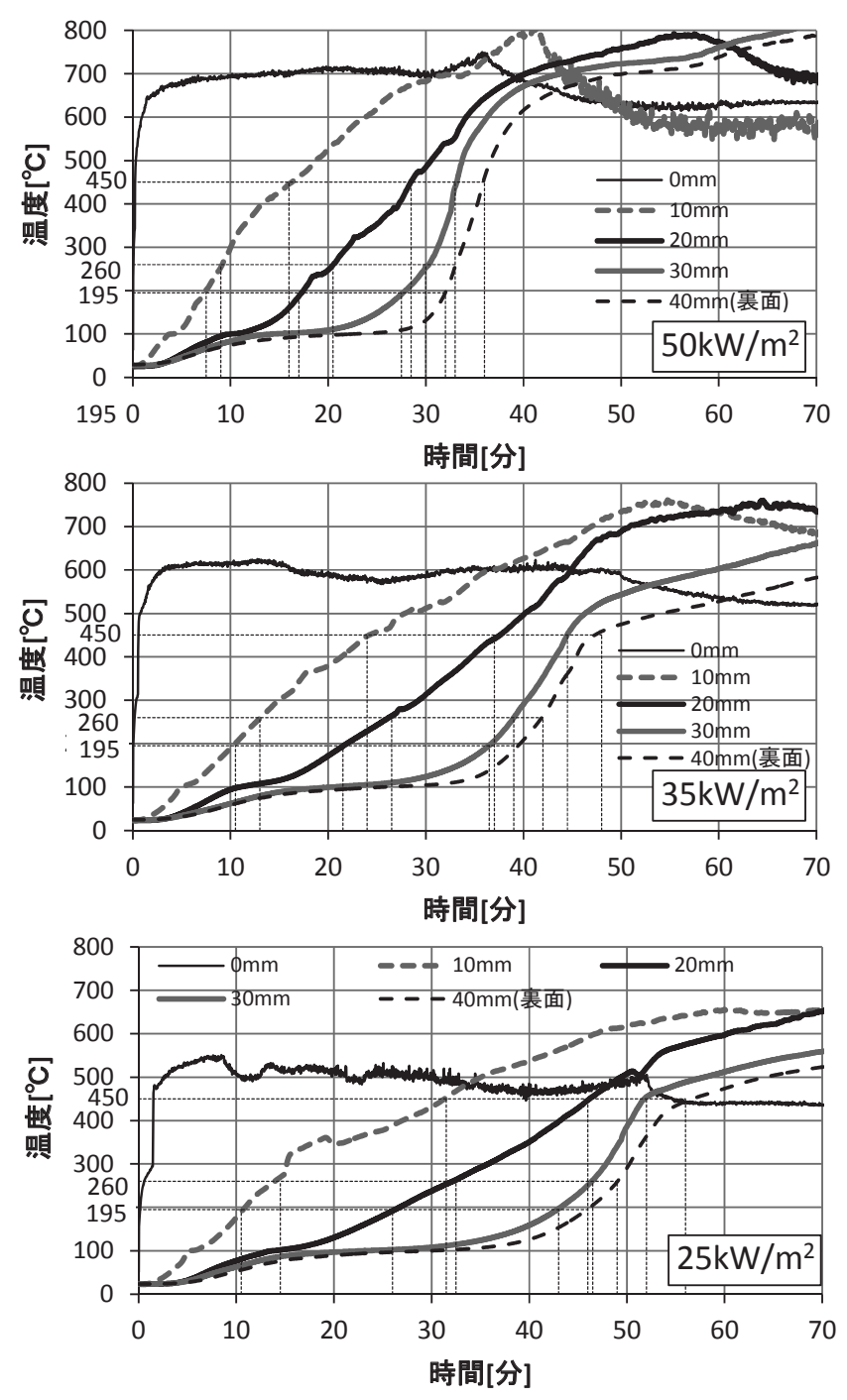

図 3 各加熱強度における内部温度推移(定常加熱実験) (上から順に加熱強度 $50,35,25 \mathrm{~kW} / \mathrm{m}^{2}$ )
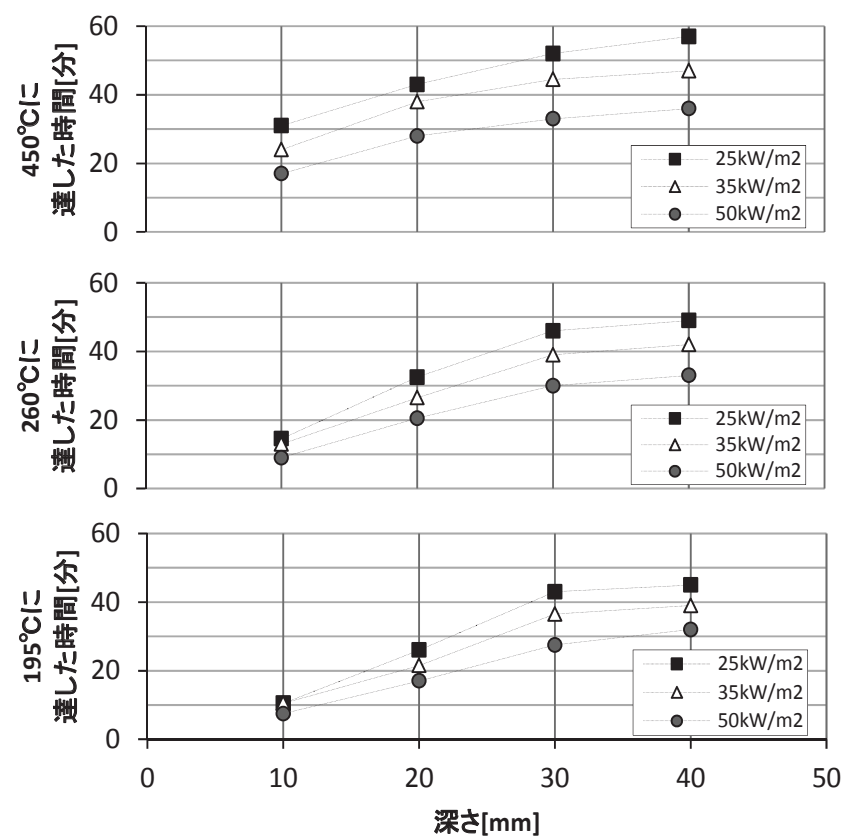

図 4 赤熱燃焼 $\left(450^{\circ} \mathrm{C}\right) \cdot$ 炭化 $\left(260^{\circ} \mathrm{C}\right) \cdot$ 薬剂分解 $\left(195^{\circ} \mathrm{C}\right)$ に達した時刻 (定常加熱実験) 


\section{3 燃え止まり型木質耐火構造部材設計への示唆}

本実験の結果から、燃えしろ層の内側に燃え止まり層を設けた場 合を考察すると、燃えしろ層厚さが $10 \mathrm{~mm}$ では加熱時の燃え止まり 層表面の熱流が大きいが、燃えしろ層厚さを増加させると赤熱燃焼 する範囲が増大し、加熱終了後の温度も上昇すると考えられる。

そこで、加熱時に燃え止まり層の温度が薬剤の分解温度に達する のを許容しながら、以下の 2 つの目標を目安として、図 3 から適正 な燃えしろ層厚さを検討する。

(1) 加熱中の燃え止まり層での吸熱を燃えしろ層の温度上昇抑制に 活用するため、加熱終了時近くに無処理材の内部温度が赤熱燃 焼帯に達する深さに燃え止まり層を設ける。

(2) 燃えしろ層において、赤熱然焼が続く範囲をできるだけ抑制する。

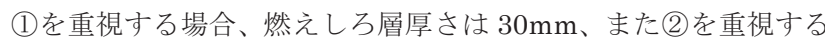
場合は $20 \mathrm{~mm}$ が適当と考えられ、燃え止まり層の難燃性能は、これ ら条件で自消を達成できるように設定する必要がある。但し、加熱 中に燃え止まり層で薬剤の分解が始まれば、その吸熱により然えし ろ層深部の温度上昇が抑制されると考えられる。よって、燃えしろ 層厚を上記のように $20 \sim 30 \mathrm{~mm}$ に設計した時の燃え止まり層加熱 側境界温度は、本実験において同じ深さで測定した温度より低くな ると考えられる。

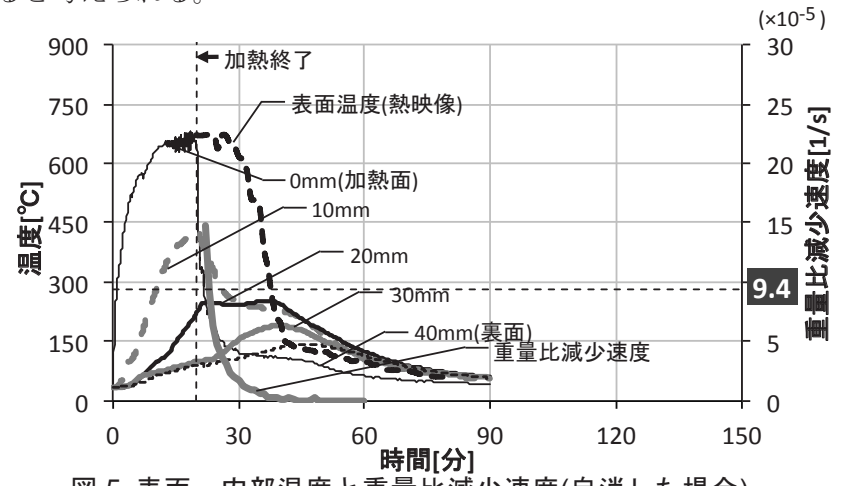

図 5 表面・内部温度と重量比減少速度(自消した場合) (加熱強度 $35 \mathrm{~kW} / \mathrm{m}^{2} \cdot$ 加熱時間 20 分)

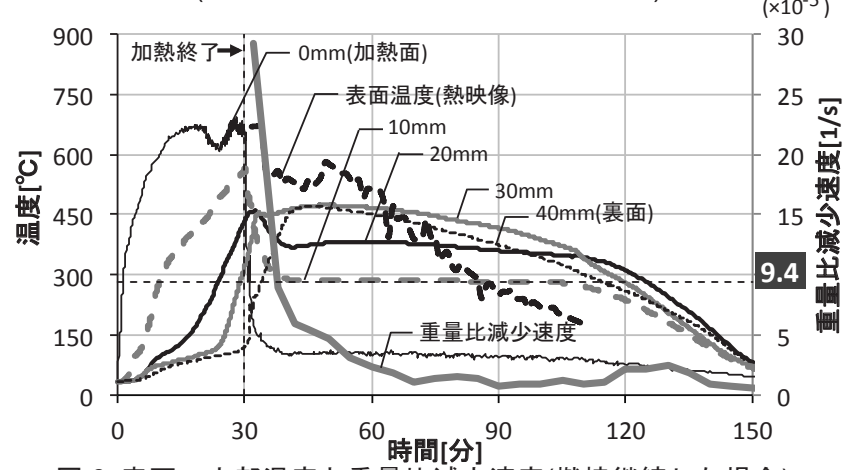

図 6 表面・内部温度と重量比減少速度(燃焼継続した場合) (加熱強度 $30 \mathrm{~kW} / \mathrm{m}^{2} \cdot$ 加熱時間 30 分)

表 1 各加熱条件における自消機構把握実験結果一覧(定常加熱実験)

\begin{tabular}{|c|c|r|r|r|r|r|r|r|r|r|r|r|r|r|r|}
\hline \\
実験結果
\end{tabular}

※1:加熱終了時に $260^{\circ} \mathrm{C}$ を超えた深さを炭化深さとする。※2:自然放冷開始を時刻 0 とする ※3:脱炉時に燃え尽きていた。
3. 火災加熱される燃え止まり型小試験体を用いた自消機構の把握 本章では、燃え止まり型木質耐火構造部材の断面の一部を再現す る試験体を製作し、小型炉を使った小型加熱実験により、標準加熱 曲線の下で自消を達成できる仕様を把握する。

前章の実験から、無処理材が厚さ $10 \mathrm{~mm}$ では、自消はするが短時 間に裏面温度が上昇するため燃え止まり層に対する被覆効果が小さ く、厚さ $40 \mathrm{~mm}$ では、加熱終了後、赤熱燃焼が持続し、燃え止まり 層が長時間加熱されると考えられる。このことから、1 時間火災加 熱に対する燃えしろ層厚さは、 $20 \mathrm{~mm} \sim 30 \mathrm{~mm}$ が適当であると予想 される。前章実験の炭化速度は標準耐火加熱時よりやや大きいが、 前述のように標準耐火加熱時の燃えしろ層の自消・赤熱燃焼も同様 の傾向を示すと仮定して、試験体の燃えしろ層厚さは、この両方の 前後の条件を含むよう、 $10 \mathrm{~mm}, 25 \mathrm{~mm}, 50 \mathrm{~mm}$ の 3 パターンとする。 いずれも、燃え止まり層は、加熱中または加熱終了後に無処理材が 赤熱燃燒に至る程度の高温に曝露されると予想でき、赤熱燃焼を抑 制できるかどうかは燃え止まり層の難燃性能による。そこで、燃え 止まり層は、防火材料として一般に流通寸る難燃処理木材の活用を 視野にいれ、難燃化の程度を準不燃材料相当と難燃材料相当の 2 パ ターンとした。実験は小型炉内にて 1 時間加熱後、4 時間自然放冷 し、自消の有無を検証する。

\section{1 実験概要}

本実験は、(国研)森林総合研究所の小型炉を用い、側面加熱にて ISO834 標準加熱曲線に沿って 1 時間加熱後、炉内で 4 時間自然放 冷した。炉の概略図を図 7 に示す。

\subsection{1 試験体}

燃え止まり型試験体(以下 FR という)は、厚さ $50 \mathrm{~mm}$ のスギ集成 材(厚さ $25 \mathrm{~mm}$ のラミナ 2 層)の上に、燃え止まり層としてスギ集成 材にリン酸系難燃処理薬剂(丸菱油化製)ンネンW2-50)を注入した 厚さ $25 \mathrm{~mm}$ のラミナ 2 層(総厚 $50 \mathrm{~mm}$ )を接着し、更に燃えしろ層と して無処理のスギラミナを接着した。各試験体の断面構成を表 2 に 示す。 $\mathrm{FR}$ 仕様は、燃えしろ層厚さ $(\mathrm{X}(\mathrm{mm}))$ と燃え止まり層の難燃薬 剂注入量 $\left(180 \mathrm{~kg} / \mathrm{m}^{3}\right.$ (準不燃材料相当)の時, $\mathrm{Y}=1 、 110 \mathrm{~kg} / \mathrm{m}^{3}$ (難燃材料 相当)の時, $\mathrm{Y}=2$ )をパラメータとして、FRX-Y で表す。以下、 $\mathrm{Y}=1$ (難 燃薬剂注入量 $180 \mathrm{~kg} / \mathrm{m}^{3}$ )のグループを $\mathrm{FR}-1, \mathrm{Y}=2\left(\right.$ 同 $\left.110 \mathrm{~kg} / \mathrm{m}^{3}\right)$ のグ ループをFR-2 という。FR の燃えしろ層厚さは前述のように $10 \mathrm{~mm}$, $25 \mathrm{~mm}, 50 \mathrm{~mm}$ の 3 通りとした。更に、無処理材と比較するために、 厚さ $25 \mathrm{~mm}$ 無処理材ラミナ 5 枚を貼り合わせて製作した仕様 $\mathrm{S}$ と あわせ、本実験の試験体は計 7 仕様とした。加熱面の大きさは、図 3.1 に示寸ように $300 \times 400 \mathrm{~mm}$ とし、各ラミナの接着には、レン゙ル シノール樹脂系接着剤を用いた。

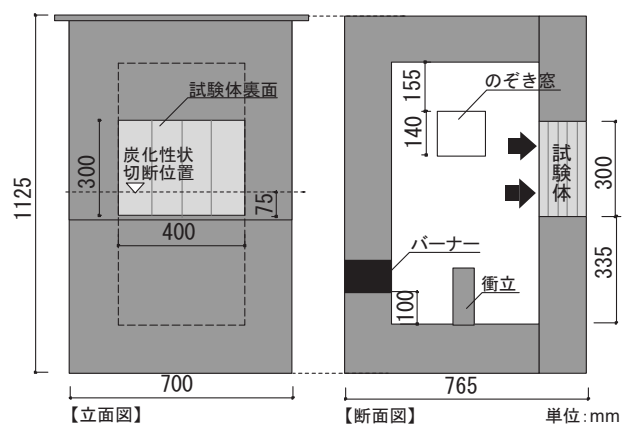

図 7 小試験体と小型炉概略図 


\subsection{2 測定項目}

炉内温度、試験体内部温度、裏面温度を測定した。内部温度の測 定には、 $\mathrm{K}$ 型シース熱電対 $(\varphi 1.0 \mathrm{~mm})$ を用い、裏面から垂直に挿入し 裏面に固定した。試験体表面及び燃えしろ層内は $5 \mathrm{~mm}$ 間隔、その 他は各部材の境界面を測定するよう $10 \mathrm{~mm}$ 間隔に設置した。裏面温 度の計測にはディスク型熱電対を用いた。測定点は表 2 に示す。

\section{2 実験結果と考察}

\subsection{1 脱炉時の試験体の状態と自消の有無}

\section{i ) 各仕様の炭化性状と自消の関係}

表 2 に実験後の試験体断面(炭化性状) と脱炉時の赤熱燃焼の有無 の観察結果を示す。以降、脱炉時に赤熱燃焼が継続していない場合 を自消したと判断する。燃え止まり層が準不燃材料相当の場合 (FR-1)、燃えしろ層が厚いほど炭化深さが大きく、厚さ 50mm(FR50-1)以外は然え止まり層内で自消したのに対し、難燃材 料相当の場合(FR-2)では、厚さ $25 \mathrm{~mm}$ (FR25-2)のみ自消した。本実 験で然え止まり層で自消した仕様があったことから、燃え止まり層 に一般的な難燃処理材を使う燃え止まり型耐火構造部材の開発が可 能であるとの見通しが得られたといえる。

2 章の実験からは、燃え止まり層は、燃えしろ層が薄ければ加熱 中に高温に曝露され、厚ければ然えしろ層の加熱終了後の赤熱燃焼 を持続させる可能性があり、燃えしろ層厚さと自消の確保の関係は 単純ではないと予想されたが、本実験では、燃えしろ層厚さと炭化 深さの関係が上記のように FR-1 と FR-2 で異なる。また、燃えし ろ層厚さ $50 \mathrm{~mm}$ では、炭化深さが FR-1,FR-2 でほぼ等しい。これ らの傾向は、燃えしろ層が薄く被覆効果が小さい場合、燃え止まり 層の温度上昇はその難燃性能に強く影響されるのに対し、加熱終了 後の燃えしろ層深部での赤熱燃焼に対する燃え止まり層の抑制効果 は、本実験試験体の燃え止まり層の 2 種類の難燃性能の間では特筆 するような差がないことを示している。

加熱終了後に燃え止まり層で赤熱燃焼が続いた FR-50-1, FR-50-2 では、いずれも自消に至らなかったことから、加熱終了後 に燃え止まり層内で赤熱燃焼が起こらないように燃えしろ層を設計 することが重要であると考えられる。

\section{ii）炭化性状と難燃薬剤注入量のばらつきの関係}

表 2 の炭化性状をみると、特に自消しなかった条件で炭化深さが 同断面内でもばらつきがある。そこで、燃え止まり層に用いたそれ ぞれ 8 枚のラミナ（加熱面側左から非加熱面右までの計 8 枚のラミ ナをそれぞれラミナ番号 $\mathrm{i}$ 〜 viii とした）ごとの難燃薬剤注入量と難 燃薬剂注入後の密度について、その平均值及び変動係数を図 8 に示 す。同一試験体のうちの 8 枚のラミナの薬剤注入量の変動係数は、 1.7 15.1 程度、ばらついていた。表 2 の炭化性状と難燃薬剂注入 量の多寡を比較すると、難然薬剤注入量が少ないラミナでは、炭化 深さが大きい傾向があるといえる。以上から、今後、より炭化性状 の予測の精度を上げるためには、難燃薬剤注入量がばらつかないよ うな対策を行うことが重要であると考えられる。なお、特に試験体 端の炭化層の剥落は脱炉時の被覆材取り外しの際に脱落した。

\subsection{2 燃え止まり層温度の推移と難燃処理木材による自消効果}

無処理材 (仕様 S) と、燃えしろ層厚さを 10、25、50mm とした仕 様 FR-1,FR-2(難燃薬剤注入量約 $180 \mathrm{~kg} / \mathrm{m}^{3}, 110 \mathrm{~kg} / \mathrm{m}^{3}$ )の計 7 仕様に おける内部温度の時間推移を図 9 に示す。但し、FR25-2 では、断
表 2 小型試験体仕様及び炭化性状結果一覧




・: 温度測定点 (1)試験体表面, (1) 燃えしろ層内部, (2)燃え止まり層表面, (3)燃え止まり層内部 (4)構造支持部表面)

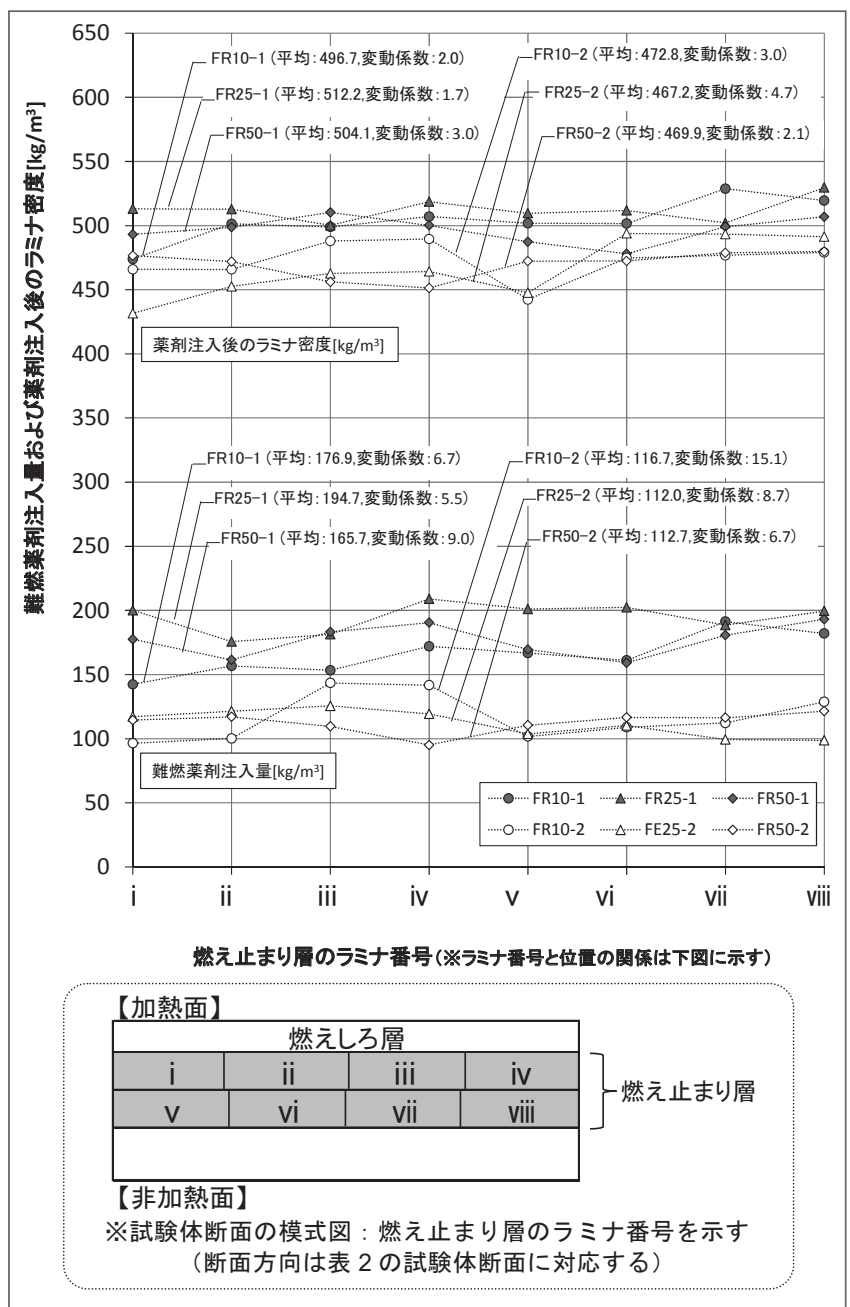

図 8 ラミナ毎の難燃薬剂注入量及び薬剤注入後の密度 $\left[\mathrm{kg} / \mathrm{m}^{3}\right]$ 
線のため 3.3〜 4.4 時間までのデータが欠落している。

i ）燃え止まり層による燃えしろ層の温度上昇抑制効果

燃え止まり層が燃えしろ層の温度上昇抑制に及ぼす効果を見るた めに仕様 S と FR25-1 とで温度推移を比較すると、表面から $15 \mathrm{~mm}$ 以内の無処理材部分では、両仕様とも類似の温度推移を辿る。しか し、FR25-1 で然え止まり層内となる 25〜35 mm では、 $200^{\circ} \mathrm{C} に$ 達 する前の温度上昇が、S では急激になるのに対し、FR25-1 では緩 慢になる。この温度差は、燃え止まり層表面が約 $195^{\circ} \mathrm{C}$ になる 47.5 分に現れ始めることから、これは難燃薬剤が $195^{\circ} \mathrm{C}$ で分解を始める こと 3$)_{4} 4$ による吸熱に起因すると考えられる。その後、この部分の 温度差の拡大に伴って、両仕様とも無処理材である表面付近でも、 $\mathrm{S}$ の方が高温になる。 $\mathrm{S}$ は、実験終了時点(5 時間)でも表面から $35 \mathrm{~mm}$ 以内では炉内温度より $40 \sim 80^{\circ} \mathrm{C}$ 程度高温であることから、少なくと も局部的には赤熱燃焼が続いていると推定される。


図 9 小型炉実験における内部温度(左:上から仕様 S,FR10-1,FR25-1,FR50-1，右:上から仕様 FR10-2,FR25-2,FR50-2)

\section{ii）燃え止まり層温度の比較と自消効果}

各条件における燃え止まり層温度(図 9 中で(3)で示す温度)を比較 すると、自消に至った条件では、最高 $220^{\circ} \mathrm{C} \sim 430^{\circ} \mathrm{C}$ と、薬剤の分 解温度を超え、赤熱然焼を超えない範囲となった。自消しなかった 条件では、FR10-2 は加熱中に約 $600^{\circ} \mathrm{C}$ 達した一方で、FR50-1, FR50-2 は加熱中に $100^{\circ} \mathrm{C} に も$ 達していない。このことから、燃焼 継続した原因として以下の 3 点が考えられる。

(1) 燃えしろ層が薄い FR10-2 では燃え止まり層自体で赤熱燃焼を 生じた。

(2) 燃えしろ層が厚い FR50-1, FR50-2 では加熱中には薬剤の分解 温度 $\left.\left.\left(195^{\circ} \mathrm{C}^{3,3}\right) 4\right)\right)$ に達せず、加熱中の燃えしろ層深部の温度上昇 の抑制に寄与できなかった。

(3) 加熱終了後、実験終了まで $200^{\circ} \mathrm{C}$ 前後が続いており、試験体内 部で続く赤熱然焼による加熱に対して薬剤の分解が持続した。

なお、仕様 $\mathrm{S}$ の内部温度は、加熱開始 60 分では深さ $25 \mathrm{~mm}$ で約 $420^{\circ} \mathrm{C} 、 35 \mathrm{~mm}$ で約 $300^{\circ} \mathrm{C}$ と、図 3 と比べるとコーンカロリーメー タによる定常加熱強度 $25 \mathrm{~kW} / \mathrm{m}^{2}$ よりやや低くなっている。

\subsection{3難燃薬剂注入量が自消性状に及ぼす影響}

表 2 及び図 9 より、仕様 FR10-1 は自消したが、仕様 FR10-2 は 燃焼継続した。難燃処理木材 FR-1 は燃えしろ層厚 10mm (FR10-1) でも自消したが、燃えしろ層が薄いため、加熱中の燃え止まり層表 面温度は FR25-1 より高い。自消したのは、燃え止まり層で炭化が 進みながらも薬剤の分解を維持することができ、温度上昇を抑制で きたためと考えられる。
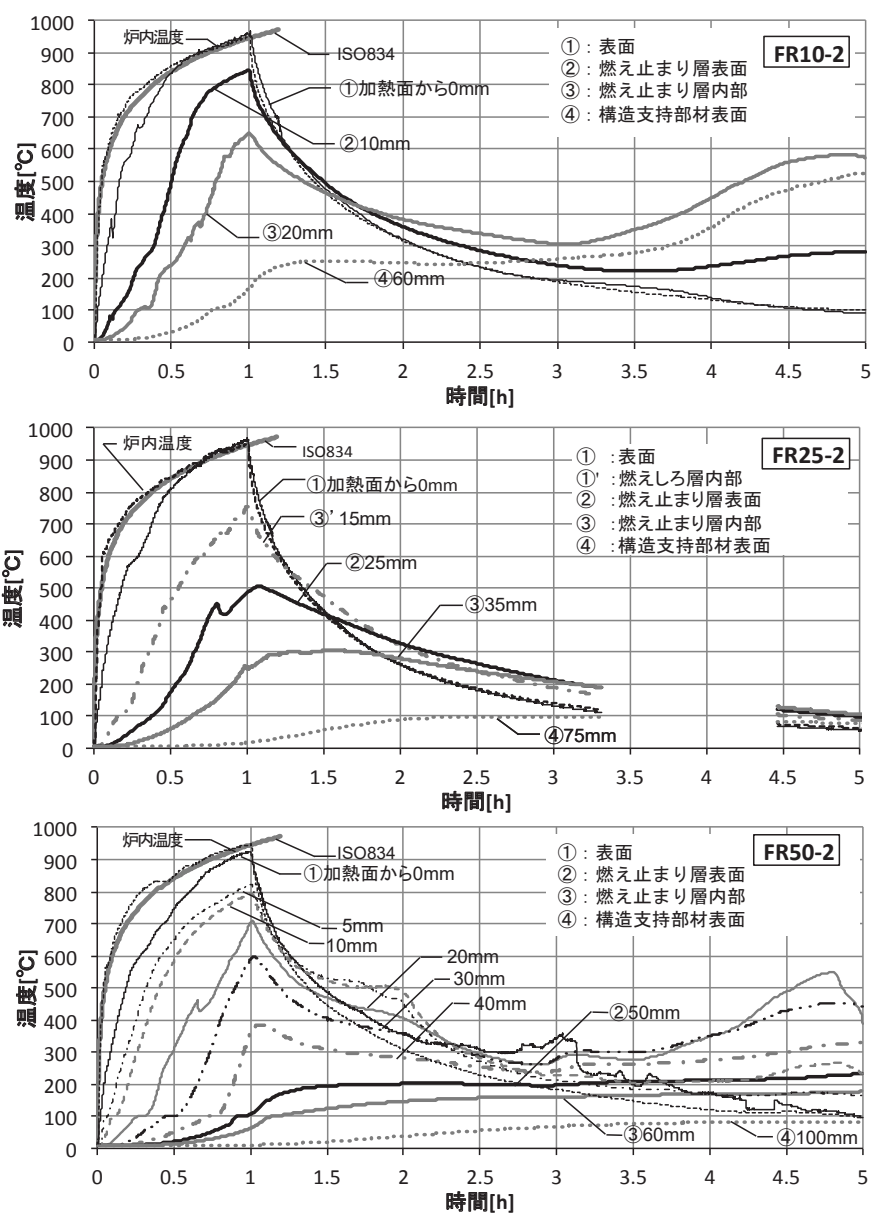
一方、FR10-2 は脱炉時に赤熱燃焼し、燃え止まり層以遠まで燃 焼が及んだ。加熱終了時に燃え止まり層内部(深さ $20 \mathrm{~mm}$ )で $450^{\circ} \mathrm{C}$ 以上であることから、加熱終了時に燃え止まり層が赤熱燃焼してい ると、自消せず燃焼継続すると考えられる。したがって、FR10-2 では、この高温での加熱に対して温度上昇を抑制するには薬剤注入 量が不足したと解釈できる。

以上から、薬剤注入量が少ないと燃え止まり層への入熱の吸収に 不十分となり、赤熱燃焼を誘発し得ることがわかる。

\subsection{4燃えしろ層厚さが自消性状に及ぼす影響}

自然放冷中の温度低下に着目寸ると、図 9 より、FR25-1、FR50-1 では加熱後、自然放冷 1 2 時間の間に表面付近で温度低下の停滞 が見られる。何れも炉内温度が $450^{\circ} \mathrm{C}$ に降下寸る前であるため、加 熱面近傍での赤熱燃焼により温度低下が妨げられたと考えられる。 炉内温度が $450^{\circ} \mathrm{C}$ より低下寸ると当該部分の温度は再び低下し始め ており、この時点で加熱面近傍の赤熱燃焼は不活発化したと考えら れる。

脱炉時には、仕様 FR50-1 で赤熱燃焼が見られたのに対し、 FR10-1 と FR25-1 では赤熱燃焼が見られなかった。仕様 FR10-1 及び FR25-1では、燃えしろ層が FR10-1でも残存していたことと、 燃え止まり層温度が難燃薬剤分解温度 $\left(195^{\circ} \mathrm{C}\right)$ 以上で難燃効果を発 揮したと考えられることから、可燃物が燃え尽きて燃焼が停止した のではなく、自消したと考えられる。

FR50-1、FR50-2 で加熱終了後、赤熱燃焼が実験終了まで継続し たのは、表面からの熱損失の影響を受け難い範囲が大きく、赤熱燃 焼による発熱速度が大きいためと考えられる。また、加熱終了の段 階で、燃え止まり層温度が薬剤の分解温度に達しなかったのは、燃 えしろ層が厚かったためである。以上か、燃えしろ層が厚ければ、 燃えしろ層深部の温度上昇の抑制と、赤熱燃焼の持続の抑止の両面 で不利になる場合があることがわかる。両仕様で、加熱終了時に深 さ $30 \mathrm{~mm}$ で赤熱燃焼温度の $450^{\circ} \mathrm{C}$ を超えているが、これは 2 章の実 験で加熱終了時に深さ $20 \sim 40 \mathrm{~mm}$ で $450^{\circ} \mathrm{C}$ 以上となり、赤熱燃焼が 進むと自消しなかったのと一致する。

\section{2 .5 自消に必要な燃えしろ層厚さと燃え止まり層の難燃性能}

以上より、燃え止まり型耐火構造で赤熱燃焼の持続を抑制するに は、加熱中に燃え止まり層表面が達する温度が、難燃薬剤の主な吸 熱反応帯に入るように燃えしろ層厚さと燃え止まり層の難燃薬剤を 選定する必要があると考えられる。即ち、燃え止まり層の設計の最 適化は燃えしろ層厚さの大小で単純に決まるわけではなく、燃えし ろ層が薄い場合は燃え止まり層に加熱中の薬剤の分解を補償できる 難燃性能を与える必要があり、燃えしろ層が厚く加熱終了後の赤熱 燃燒を抑止できなければ、長時間の赤熱燃焼による加熱に耐える難 燃性能を燃え止まり層に与えなければならない。また、本実験で見 られた自消の有無と燃えしろ層厚さ・燃え止まり層の難燃性能の関 係は、2 章の実験で観察された赤熱燃焼の持続の有無と共通し、本 実験で燃えしろ層厚 $25 \mathrm{~mm}$ の時に難燃性能の低い燃え止まり層で も自消を達成できたことは、 2 章の実験から予想可能な範囲にある。 これより、難燃処理材を燃え止まり層とする燃え止まり型耐火構造 の適正然えしろ厚さは、燃えしろ層に使用する木材の火災加熱時の 内部温度推移を把握できれば、赤熱然焼温度と燃え止まり層に使用 寸る薬剤の分解温度を手がかりとして、予想できると考えられる。

\section{4. 燃え止まり型耐火構造梁の設計と有効性の検証}

\section{1 目的及び試験体設計内容}

本章では、前章までの検討の燃え止まり型耐火構造部材の設計 の適用について妥当性を検討するために、別途、燃え止まり型木質 耐火構造の梁として検討されている仕様 9)を利用して、燃えしろ層 及び燃え止まり層を設計し、実大断面の試験体を用いた 1 時間の耐 火構造の加熱実験を非載荷で行った。本実験では、3 章同様、炉内 温度をISO834 標準加熱曲線に従って制御する。耐火加熱実験では、 炉内温度が同一となるように制御しても炉の構造・規模、試験体と 温度測定位置の違いにより試験体への入熱に差が生じ得るが、ここ では、3 章の小型実験における炭化速度が、実大規模の耐火加熱試 験時と大きくは違わないことから、小型加熱実験の結果を参照して 部材を設計した。

本実験で用いた仕様 9)の燃え止まり層は荷重支持部側面が難燃処 理合板、下面がせっこうボード(21 mm 3 枚張) となっている。側面 の燃えしろ層は、厚さ $30 \mathrm{~mm}$ の集成材単板を積層する設計のため、 その厚さは、 3 章より燃え止まり層を準不燃材料相当とした時に自 消の可能性を期待できる $30 \mathrm{~mm}$ と赤熱然焼の継続が予測される $60 \mathrm{~mm}$ の 2 種類とした。試験体は全長 $1000 \mathrm{~mm}$ 、荷重支持部断面を $200 \times 300 \mathrm{~mm}, 200 \times 900 \mathrm{~mm}$ の 2 通りとした。

表 3 実大梁加熱実験試験体仕様及び主要結果一覧

\begin{tabular}{|c|c|c|c|c|c|}
\hline & 試験体名 & $\mathrm{E}$ & $\mathbf{F}$ & G & $\mathrm{H}$ \\
\hline & 燃えしろ層樹種 & \multicolumn{4}{|c|}{ スギ集成材 } \\
\hline \multirow{8}{*}{ 慗 } & 燃えしろ層厚さ[mm] & 30 & 60 & 30 & 60 \\
\hline & 構造支持部樹種 & \multicolumn{4}{|c|}{ スギ集成材 } \\
\hline & 構造支持部材断面 [mm] & 200 & 300 & 200 & $<900$ \\
\hline & 含水率(スギ集成材)[\%] & 11.5 & 10.6 & 11.2 & 9.6 \\
\hline & 燃え止まり層樹種 & \multicolumn{4}{|c|}{ スギ難燃処理合板 } \\
\hline & 燃え止まり層厚さ[mm] & \multicolumn{4}{|c|}{ 45(厚さ15×3枚） } \\
\hline & 薬剂種類·固定量 & \multirow{2}{*}{\multicolumn{4}{|c|}{$\begin{array}{c}\text { ハンネンW2-50・140 150kg/m } \\
\text { レゾルシノール樹脂接着剂 }\end{array}$}} \\
\hline & 接着剂 & & & & \\
\hline 畔 & 最大炭化深さ [mm] & 60 & 86 & 67 & 105 \\
\hline 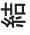 & 自消判定 & 自消した & 燃焼継続 & 自消した & 燃焼継続 \\
\hline
\end{tabular}



図 10 水平炉試験装置 概略図(実大梁加熱試験) 
また、本実験用試験体の製作にあたつて利用可能な難燃処理合板の 薬剤注入量は最大で $140 \sim 150 \mathrm{~kg} / \mathrm{m}^{3}$ であった。3 章の実験では、燃 え止まり層 $25 \mathrm{~mm}$ で、薬剤注入量 $110 \mathrm{~kg} / \mathrm{m}^{3}$ 及び $180 \mathrm{~kg} / \mathrm{m}^{3}$ のどち らでも、自消した。但し、薬剤注入量が少ない試験体では、炭化深 さが大きい傾向があり、注入量の変動係数も低注入量ほど大きい傾 向が認められた。本章の実大実験では、それらを考慮して、概ね中 間值である薬剤注入量 $140 \sim 150 \mathrm{~kg} / \mathrm{m}^{3}$ の難燃合板を燃え止まり層 とし、燃えしろ層の厚さを適切に設定することを考えた。試験体仕 様を表 3 に示す。なお、試験体の小口は熱が進入しないように耐火 材で被覆した。

\section{2 実験概要}

(国研)建築研究所の水平炉 $(4300 \times 4000 \mathrm{~mm})$ を用い、試験体 4 体を 同時に ISO834 標準加熱曲線に沿って 1 時間加熱後、炉内にて 23 時間自然放冷した後、脱炉した。測定項目は、試験体内部温度及び 炉内温度 $\left[{ }^{\circ} \mathrm{C}\right]$ とした。内部温度測定には $\mathrm{K}$ 型熱電対 $(\varphi 0.65 \mathrm{~mm})$ を使 用し、加熱面から $10 \mathrm{~mm}$ 間隔を基準に設置した。炉内の試験体の配 置及び温度測定点を、それぞれ図 10、図 11 に示す。

\section{3 実験結果 · 考察}

各仕様の脱炉時の炭化性状を図 11 に、加熱開始から脱炉までの 内部温度を図 12〜15 に示す。仕様 $\mathrm{E}, \mathrm{G}$ (燃えしろ層厚 $30 \mathrm{~mm}$ )では、 図 11 から然えしろ層の炭化層がほとんど脱落せずに残存したまま 鎮火していたことから、自然放冷中に炭化層の赤熱燃焼は起こらず に自消したと推定される。燃え止まり層は、加熱終了時までに一層
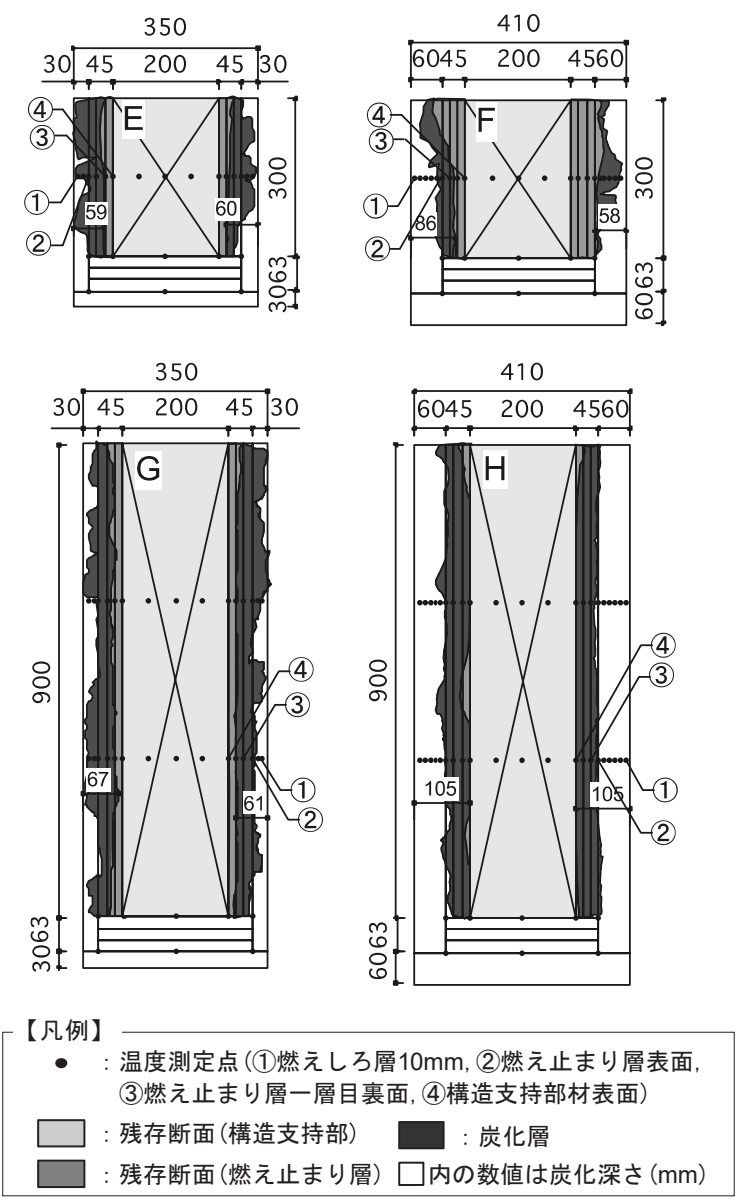

図 11 温度測定点及び脱炉時の炭化性状 (実大梁加熱実験) (左上:仕様 $E$, 右上:仕様 $F$, 左下:仕様 G, 右下:仕様 $H$ )

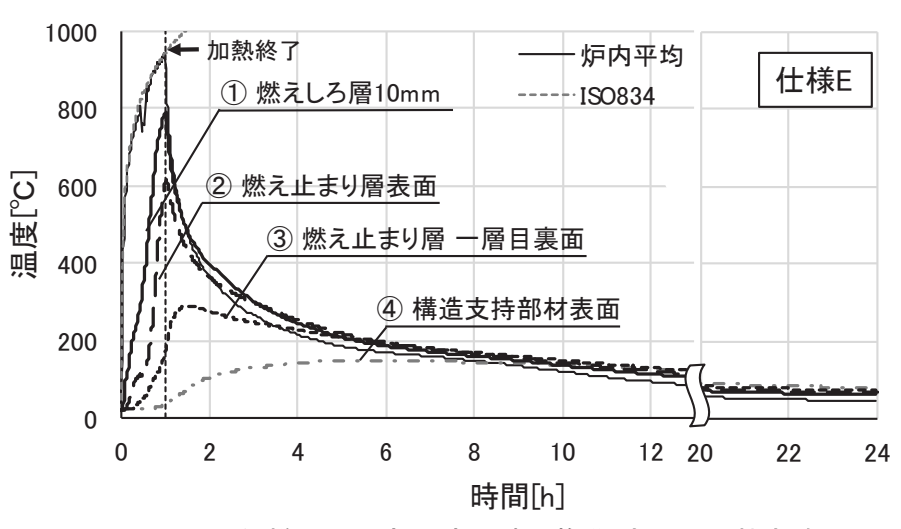

図 12 仕様 $E$ の内部温度の時間推移(実大梁加熱実験)

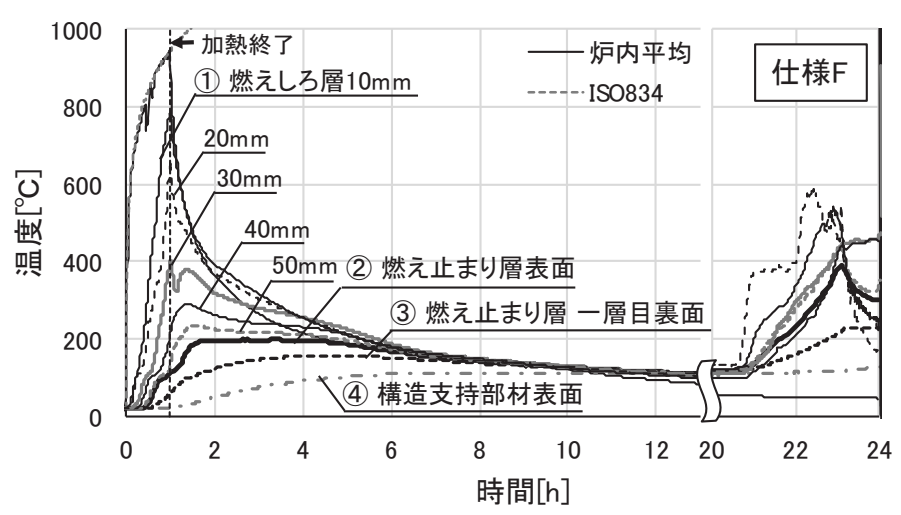

図 13 仕様 $F$ の内部温度の時間推移(実大梁加熱実験)

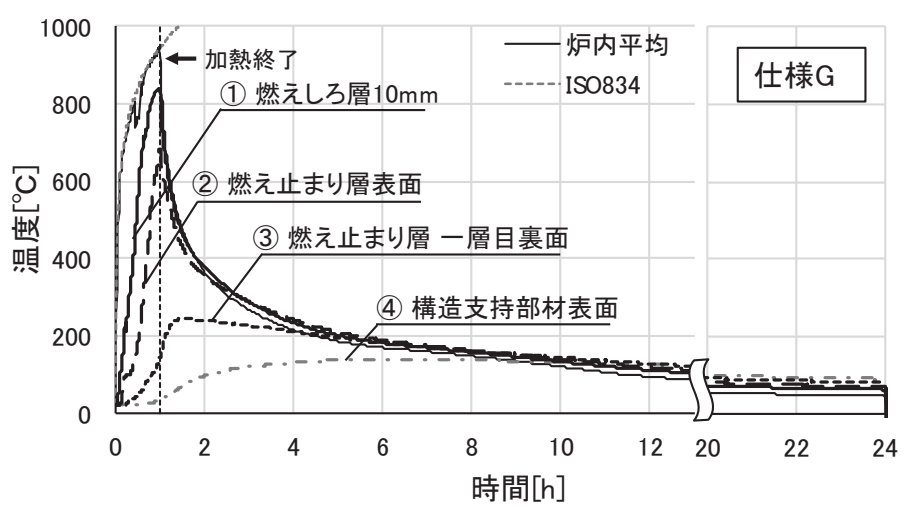

図 14 仕様 G の内部温度の時間推移(実大梁加熱実験)

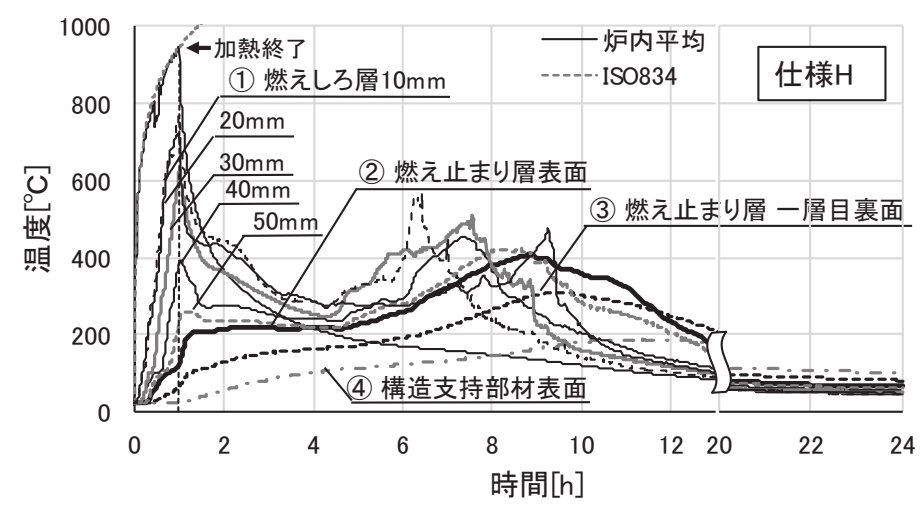

図 15 仕様 $\mathrm{H}$ の内部温度の時間推移(実大梁加熱実験) 
目裏面(3))が薬剤の分解温度(約 $195^{\circ} \mathrm{C}$ (3),5) に達しており(図 12 、図 14)、分解に伴う吸熱により燃えしろの温度上昇抑制に寄与したと考 えられる。

一方で、仕様 $\mathrm{F}, \mathrm{H}$ (燃えしろ層厚 $60 \mathrm{~mm}$ ) では、脱炉時に炭化層の 亀裂部分に赤熱燃焼を確認した。燃えしろ層は概ね赤熱燃焼により 燃え尽きたと考えられ(図 11)、一部中心部材まで然え込んでいた。 図 13、図 15 から、燃え止まり層表面(2) は、加熱終了時に薬剤の 分解温度に達していないことがわかった。また加熱終了後、長時間 $200^{\circ} \mathrm{C}$ 前後で停滞しているが、これは加熱中に燃えしろ層での赤熱 燃焼の発生を抑制できないまま、加熱終了後は赤熱然焼する燃えし ろ層から燃え止まり層への入熱が薬剂を消費して、再燃の原因にな った可能性がある。部材内部温度は加熱終了後、概ね緩慢に低下し ているが、仕様 $\mathrm{F}$ では 20 時間前後、仕様 $\mathrm{H}$ では 4.5 時間前後で部 材内部温度が炉内温度より目立って高くなるのは、赤熱燃焼が局所 的に持続していたことを示している。

\section{4 燃え止まり型耐火部材設計における適正寸法と難燃性能}

本実験では、3 章で示した小型加熱実験の結果に基づいて断面を 設計した燃え止まり型耐火構造部材の自消性を実大規模で検証でき た。これにより、燃え止まり型木質耐火構造部材の設計を、燃えし ろ層・燃え止まり層を再現した小型試験体による加熱実験に基づい て行える見通しが得られたといえる。更に、部材設計の指針として、 燃え止まり層温度が加熱中に薬剂の分解温度に達し、加熱終了後は 燃えしろ層の温度を赤熱燃焼の温度带未満に留められるよう、燃え 止まり層への入熱と薬剤の分解による吸熱の平衡を維持できるよう にすることが重要であることがわかった。

\section{5. まとめと今後の課題}

燃え止まり型耐火構造において制御が必要な木材の赤熱燃焼には 未解明な点が多く、自消の理論的予測に必要な難燃処理木材の高温 での熱物性や反応特性の把握も容易ではない。

本研究では、この状況の元で、小型試験に基づいて燃え止まり型 耐火構造部材仕様を合理的に設計する手順を検討した。その結果、 材料試験や小型炉による加熱試験により、燃えしろ層の厚さと燃え 止まり層の難燃性能を選択し、最終的に実大規模の加熱試験で検証 する手法を考案して、実際に、実大部材レベルで、構造部材の着火 を防いで自消可能な仕様を開発することができた注 11

本研究の過程で、燃え止まり型耐火部材において、加熱終了後の 燃焼継続は赤熱燃焼に由来することを確認し、部材の設計指針とし て以下の 3 点を明らかにした。

(1) 燃えしろ層厚さは、薄いと火災加熱中に燃え止まり層に対する 被覆効果を失い燃え止まり層で赤熱燃焼を誘発する一方、厚い と赤熱燃焼が加熱終了後も続き、燃え止まり層では自消を確保 できなくなる可能性がある。このため、燃えしろ層には、燃え 止まり層に必要な難燃性能が最小となる最適厚さが存在する。

(2) 燃え止まり層に必要な難燃性能を最小化するには、加熱中に燃 え止まり層で薬剤の分解温度に達して、その吸熱により燃えし ろ層深部の温度上昇を抑制し、加熱終了時に赤熱燃焼に至らな い限界となるようにすることを目安に燃えしろ層厚さと燃え
止まり層の難燃性能を設計すれば良い。このうち、燃えしろ層 の最適厚さは、赤熱燃焼温度及び燃え止まり層の難燃薬剤の分 解温度に基づき、無処理材加熱時の温度推移から推定できる。 (3) 無処理のスギを燃えしろ層として 1 時間耐火構造とする場合、 燃え止まり層に必要な難燃性能を最小化するには、燃えしろ層 厚さを 20 〜 $30 \mathrm{~mm}$ とする必要がある。

この方法でも、実験による試行錯誤は必要であるが、広く普及し ている小型試験のレベルである。木質耐火構造部材の従来の一般的 な研究開発に比べて、利用できる地域が限られる大規模な炉を使わ ずに検討を進められること、検討に必要な費用・労力・時間を大幅 に削減できることなど、研究開発への取り組みを容易にする見通し が得られたと考える。なお、この方法で試行錯誤を必要とするのは、 主に燃え止まり層の難燃性能の設定に関わる部分であり、加熱され る無処理材裏面に接する難燃処理木材の伝熱及び分解による吸熱過 程をより工学的に把握できるようになれば、この手順もより単純化 できると考える。

\section{謝辞}

本研究は科学研究費「大断面木質部材の防耐火性能設計の工学モ デル」(研究代表者：長谷見雄二)の一環として実施しました。本研 究を行うにあたり、(国研) 森林総合研究所をはじめ、実験及び試験 体の製作に関わった皆様には多大なるご助言、ご協力を頂きました。 ここに深く感謝の意を表します。

注

注 1)本研究に基づいて燃えしろ層厚さを決定した燃え止まり型耐火構造梁が、 1 時間耐火構造として性能評価を受けている(性能評価機関名：一般財団法 人ベターリビング、性能評価番号：KE-C002-15「スギ集成材・強化せっこ うボード・難燃処理合板被覆/スギ構造用集成材はり」)。

\section{参考文献}

1)上川大輔ら：耐火集成材の開発，その 2 , 表層とコアを無処理ラミナとした 集成材柱の燃え止まり, 日本建築学会大会学術講演梗概集, 防火, pp85-86, 2007

2)石川敬ら：燃え止まり型木質構造梁における燃えしろ層の適正寸法の検討, その 2, せいの高い梁の検討, 日本建築学会大会学術講演梗概集, 防火, pp277-278, 2014

3)山口智世ら：火災加熱される木質部材の熱分解・燃焼性状のモデル化に向 けた基礎研究, 日本建築学会大会学術講演梗概集, 防火, pp469-472, 2013

4)山口智世ら：木材の燃焼過程のモデル化に向けた熱物性值の把握, 日本建築 学会大会学術講演梗概集，防火,pp245-246, 2014

5)高瀬椋ら：燃え止まり型木質耐火構造部材の工学的設計手法に関寸る研究, その 1 , 木材の自消条件から見た燃えしろ・燃え止まり層の最適設計の検 討, 日本建築学会大会学術講演梗概集, 防火, pp139-142, 2015

6)山口智世ら：燃え止まり型木質耐火構造部材の工学的設計手法に関する研 究，その 2 , 実大部材への適用及び数值的設計手法の開発可能性の検証，日 本建築学会大会学術講演梗概集, 防火, pp109-110, 2015

7)原田和典ら: 木質構造部材の炭化性状に関寸る数值解析, 日本建築学会近畿 支部研究報告集，pp209-212, 2004

8)安井昇ら：局所火源を前提とする木質系耐火設計に関する研究，その 2 , 耐 火性能評価からみた木材(高知県産スギ)の放射加熱応答性状, 日本建築学 会大会学術講演梗概集, 防火, pp29-30,2005

9)景山悠太郎ら: スギ難燃処理合板を利用した木質耐火構造部材の開発，その 4, 小型加熱実験, 日本建築学会大会学術講演梗概集, 防火, pp317-318, 2009 


\title{
ENGINEERING APPROACH TO THE DESIGN OF WOODEN FIREPROOF STRUCTURAL ELEMENTS BASED ON THE SACRIFICE-LAYER CONCEPT
}

Optimum design of the wood-based protection layers using bench-scale tests

\author{
Tomoyo YAMAGUCHI*1, Daisuke KAMIKAWA ${ }^{* 2}$, Yuji HASEMI ${ }^{* 3}$, Noboru YASUI*4, \\ Ryo TAKASE ${ }^{* 5}$, Masayuki MIYABAYASHI ${ }^{* 6}$ and Jun-ichi SUZUKI ${ }^{* 7}$ \\ *1 Takenaka Corporation, M.Eng.(formerly Waseda University) \\ ${ }^{* 2}$ Forestry \& Forest Products Research Institute, Dr.Eng. \\ ${ }^{* 3}$ Prof., Dept. of Architecture, Waseda University, Dr.Eng. \\ ${ }^{* 4}$ Visiting Researcher, RISE, Waseda University, Dr.Eng. \\ ${ }^{* 5}$ Graduate School of Waseda University \\ ${ }^{*} 6$ T.E.Consulting Inc. \\ ${ }^{* 7}$ National Institute for Land Infrastructure Management, Dr.Eng.
}

The concept of the Fireproof construction in the Japanese building regulation was redefined in the year 2000 to enable wood based large buildings as assemblies sustaining its permanent load bearing capability even after required fire endurance time. Because of the essential difficulty in achieving this requirement for wood, its development is still very slow except for the wooden structures with inorganic protection. The target of this study is the Fireproof assemblies composed of load bearing part at the center, barrier(fire retardant treated plywood) and sacrifice layer(chemically untreated wood), whose development is the most behind among various types of the wood-based Fireproof construction. In order to minimize the use of large-scale furnaces, following three series of tests are conducted.

(1)Measurement of internal temperatures of thick slab of chemically untreated wood exposed to stationary radiative heating. (2)Measurement of internal temperatures of slab specimens simulating the near-surface section of wooden assembly based on the sacrifice-layer concept designed according to the result of the series(1) tests exposed to one-hour standard fire-resistance heating and left in quiescent environment afterwards.

(3)Furnace test of beam specimens with full scale section designed from the series(2) tests as one-hour Fireproof construction Japanese cedar, the most popular wood in Japan, was used for all the specimens. Through the series(1) tests, it was clarified that wood not closer than $20 \mathrm{~mm}$ from its surface is only weakly affected by the surface heating or cooling and may sustain glowing combustion even after the end of fire heating once the local temperature reaches the range for glowing combustion. On the other hand, heat flux near the surface during fire heating tends to be strong enough to damage the endothermic effect of the barrier. From the series(1) tests, it was concluded that $20-30 \mathrm{~mm}$ be the optimum thickness for the sacrifice layer of an one-hour Fireproof construction, not damaging the function of the barrier during the fire exposure and not causing significant glowing combustion within the sacrifice layer afterward.

Series(2) tests were conducted with specimens with $10 \mathrm{~mm}, 25 \mathrm{~mm}$ and $50 \mathrm{~mm}$ sacrifice layers and two fire-retardant levels of fire retardant treated plywood for the barrier, corresponding to the Fire-retardant and Quasi-noncombustible materials. The specimens with the Fire-retardant plywood barrier succeeded in protecting the load-bearing part only when the sacrifice layer was $25 \mathrm{~mm}$ thick; it verifies the optimum sacrifice layer thickness assumed from the series(1) tests. The specimens with Quasi-noncombustible plywood succeeded with both $10 \mathrm{~mm}$ and $25 \mathrm{~mm}$ thick sacrifice layers. These results reveal the achievability of Fireproof construction with barrier of widely available fire retardant treated plywood.

At the series(3) large furnace tests, a specimen of beam with $30 \mathrm{~mm}$ thick sacrifice layer and the Quasi-fireproof plywood barrier succeeded in achieving the integrity as one-hour Fireproof construction.

From these tests, the following conclusions can be drawn.

(1) There is an optimum thickness range for the sacrifice layer for the Fireproof construction. Thinner sacrifice layer may damage the function of the barrier during fire heating and thicker sacrifice layer will result in the activation of glowing combustion after the fire heating.

(2) Fire retardant capacity of the barrier can be minimized if the vaporizing temperature of the fire retardant treated wood is chosen to meet the temperature of the back surface temperature of the sacrifice layer during the heating.

The stages (1) and (2), essential parts of the developing process of Fireproof construction, do not need any large scale or scarce test apparatuses. It implies that, unlike most of previous developments of wood-based Fireproof construction, this method can be effective in any district where only conventional bench-scale test apparatuses are available. 